spur was also a first; five were seen by Stuart and Mary Houston and Jonathan Gerrard.

SPECIES LIST: Red-necked Grebe, Horned Grebe, Eared Grebe, Western Grebe, Pied-billed Grebe, White Pelican, Whistling Swan, Canada Goose, White-fronted Goose, Mallard, Gadwall, Pintail, Green-winged Teal, Blue-winged Teal, American Widgeon, Shoveler, Redhead, Ringnecked Duck, Canvasback, Lesser Scaup, Common Goldeneye, Bufflehead, Ruddy Duck, Cooper's Hawk, Red-tailed Hawk, Swainson's Hawk, Ferruginous Hawk, Marsh Hawk, Peregrine Falcon, Sparrow Hawk, Ruffed Grouse, Sharp-tailed Grouse, Gray Partridge, Sandhill Crane, Sora, American Coot, Semipalmated Plover, Killdeer, American Golden Plover, Black-bellied Plover, Ruddy Turnstone, Common Snipe, Long-billed Curlew, Upland Plover, Spotted Sandpiper, Solitary Sandpiper, Willet, Lesser Yellowlegs, Pectoral Sandpiper, Baird's Sandpiper, Least Sandpiper, Stilt Sandpiper, Semipalmated Sandpiper, Marbled Godwit, Sanderling, American Avocet, Wilson's Phalarope, Northern Phalarope, California Gull, Ring-billed Gull, Franklin's Gull, Common Tern, Black Tern, Rock Dove, Mourning Dove, Burrowing Owl, Common Nighthawk, Yellow- shafted Flicker, Yellow - bellied Sapsucker, Hairy Woodpecker, Downy Woodpecker, Eastern Kingbird, Western Kingbird, Eastern Phoebe, Least Flycatcher, Horned Lark, Tree Swallow, Bank Swallow, Barn Swallow, Purple Martin, Blue Jay, Black-billed Magpie, Common Crow, Black-capped Chickadee, Brown Creeper, House Wren, Short-billed Marsh Wren, Catbird, Brown Thrasher, Robin, Swainson's Thrush, Gray-cheeked Thrush, Veery, Mountain Bluebird, Ruby-crowned Kinglet, Water Pipit, Sprague's Pipit, Loggerhead Shrike, Starling, Black-and-white Warbler, Tennessee Warbler, Orange-crowned Warbler, Yellow Warbler, Myrtle Warbler, Blackpoll Warbler, Bay-breasted Warbler, Palm Warbler, Ovenbird, Northern Waterthrush, Yellowthroat, Wilson's Warbler, American Redstart, House Sparrow, Western Meadowlark, Yellow-headed Blackbird, Redwinged Blackbird, Baltimore Oriole, Brewer's Blackbird, Common Grackle, Brown-headed Cowbird, Rose-breasted Grosbeak, Rufous-sided Towhee, Savannah Sparrow, Baird's Sparrow, Vesper Sparrow, Lark Sparrow, Slate-colored Junco, Chipping Sparrow, Clay-colored Sparrow, Harris' Sparrow, White-crowned Sparrow, White-throated Sparrow, Lincoln's Sparrow, Song Sparrow, Lapland Longspur, Smith's Longspur, Chestnutcollared Longspur.-Jim Slimmon, Compiler.

\title{
SOME INTERESTING BIRD RECORDS FOR CENTRAL SASKATCHEWAN
}

From about July 22 to August 12, 1961 Dr. Mary M. Tremaine, microbiologist on the faculty of the University of Nebraska and a well-known amateur ornithologist, travelled in Saskatchewan on a bird-finding tour. Although she made detailed notes these have since been lost. However, a few of her observations, which were reported in correspondence with the editor shortly after her trip and recently, are noteworthy even though precise data are lacking.

Wood Duck, one, Duck Lake, near Carlton.

Arctic Tern (?), five, seen flying over Montreal Lake (south of La Ronge) during a mile walk along the east lake shore. "In spite of my experience, or perhaps because of it, I will always hesitate on Arctic Terns in late summer. These had the greyer mantle, greyer side of head, red bills, but with some black. I think they were Arctics, but who knows?" (pers. corres. to R. Nero, August 16, 1961). "I questioned the Arctic Terns because they didn't perch and I couldn't verify the short legs ... We had them on Cape Cod and Nova Scotia, too, so I've had pretty good looks at them." (pers. corres. to R. Nero, 1965).

Caspian Tern, one, flying over Montreal Lake.

Barred Owl, one, Little Sandy Lake, near MacDowall.

Great Gray Owl (?), two, near Torch River. "I saw two very large owls at night on a bridge rail - not Great Horned and not Barred - absolutely immense. I thought they were probably Great Gray Owls. They flew off down the road ahead of my lights and disappeared." (pers. corres. to R. Nero, 1965).

Townsend's Solitaire, one, east side of Fishing Lake, Nipawin Provincial Forest.

Evening Grosbeak, some along the road north of La Ronge.

\section{NEST RECORDS}

You are reminded that nest records for the 1965 season should be sent to the Prairie Nest Records Scheme, c/o Robert R. Taylor, Box 1121, Regina. If you need more nest record cards, write to the same address. 